\title{
KEPASTIAN HUKUM IMPLEMENTASI PRIORITAS PEMBERDAYAAN UMKM DALAM PENGADAAN BARANG/JASA
}

\author{
Hans Joy Tarigan, Bismar Nasution, Sunarmi, Mahmul Siregar \\ Program Studi Magister Ilmu Hukum, Fakultas Hukum ,Universitas Sumatera Utara \\ Email : hansjoytarigan@gmail.com
}

\begin{abstract}
ABSTRAK
Usaha Mikro Kecil dan Menengah (UMKM) yang menghasilkan berbagai barang/jasa, diselenggarakan dengan tujuan untuk menumbuhkan dan mengembangkan usaha dalam rangka membangun perekonomian nasional/daerah berdasarkan demokrasi ekonomi yang berkeadilan. Pemenuhan kebutuhan Pemerintah Daerah (Pemda) akan barang/jasa yang dibutuhkan sebagai upaya memenuhi kebutuhan masyarakat dan memenuhi kebutuhan Pemda dalam menyelenggarakan pemerintahan daerah, dapat dilakukan melalui kegiatan pengadaan barang/jasa (procurement), yang mempunyai peran penting dalam pelaksanaan pembangunan untuk peningkatan pelayanan publik dan khususnya untuk pengembangan perekonomian di daerah. Untuk itu maka kegiatan pengadaan barang/jasa pada Pemda, dalam implementasinya idealnya diprioritaskan memberdayakan UMKM. Hasil pembahasan menyimpulkan bahwa belum sepenuhnya tercipta kepastian hukum mengenai implementasi prioritas permberdayaan UMKM dalam pengadaan barang/jasa pada Pemda. Hal tersebut dikarenakan belum ada ketentuan pasal dalam Undang-Undang Nomor 20 Tahun 2008 Tentang Usaha Mikro, Kecil, dan Menengah (UU Nomor 20 Tahun 2008) maupun dalam Peraturan Presiden Nomor 16 Tahun 2018 Tentang Pengadaan Barang/Jasa Pemerintah (Perpres Nomor 16 Tahun 2018), yang menentukan mengenai kewajiban hukum Pemda untuk mengimplementasikan prioritas pemberdayaan UMKM dalam kegiatan pengadaan barang/jasa pada Pemda.
\end{abstract}

\section{Kata Kunci: Kepastian Hukum, Pemberdayaan, UMKM, Pengadaan,Barang/Jasa}

\section{ABSTRACT}

Micro, Small, and Medium Enterprises (MSME)s that produce various goods/services, are held with the aim of growing and developing businesses in order to build a national/regional economy based on equitable economic democracy. The fulfillment of regional government needs of goods/services needed as an effort to meet the needs of the society and meet the needs of local governments in carrying out regional governments, can be done through procurement activities, which have an important role in the implementation of development to improve public services and especially for the development of the economy in the region. Therefore the procurement activities in the regional government, in its implementation are ideally prioritized empowering MSMEs. As conclusion, that has not fully created legal certainty regarding the implementation of the priority of the empowerment of MSMEs in procurement in local governments. This was confirmed because there was no provision of article in Law Number 20 Year 2008 Concerning Micro, Small, and Medium Enterprises (Law Number 20 Year 2008) and Presidential Regulation Number 16 Year 2018 Concerning Government Procurement (Presidential Regulation Number 16 Year 2018), which decided on the legal obligations of regional governments to implement the priority of the empowerment of MSMEs in procurement in the regional government.

Keywords:Legal Certainty, Empowerment, UMKM, Procurement, Goods/Services 


\section{A. PENDAHULUAN}

Pada era otda, barang/jasa yang harus dipenuhi bukan saja menjadi kebutuhan Pemerintah, akan tetapi juga menjadi kebutuhan Pemda, baik Pemerintah Propinsi (Pemprop) maupun Pemerintah Kabupaten/Pemerintah Kota (Pemkab/Pemko). ${ }^{1}$ Tersedianya barang/jasa disamping merupakan bagian dari tugas dan tanggung jawab setiap Pemda dalam upaya memenuhi kebutuhan masyarakatnya, juga sekaligus pemenuhan kebutuhan Pemda dalam menyelenggarakan pemerintahan daerah. ${ }^{2}$

Pemenuhan kebutuhan Pemda akan barang/jasa yang dibutuhkan sebagai upaya memenuhi kebutuhan masyarakat dan memenuhi kebutuhan Pemda dalam menyelenggarakan pemerintahan daerah, dapat dilakukan melalui kegiatan pengadaan barang/jasa. Kegiatan pengadaan barang/jasa pada Pemda mempunyai peran penting dalam pelaksanaan pembangunan untuk peningkatan pelayanan publik dan khususnya untuk pengembangan perekonomian. ${ }^{3}$ Kegiatan pengadaan barang/jasa pada Pemda sebagai upaya memenuhi kebutuhan masyarakat dan memenuhi kebutuhan Pemda dalam menyelenggarakan pemerintahan daerah tentunya haruslah dilakukan sesuai dengan ketentuan Perpres Nomor 16 Tahun $2018 .^{4}$

Terkait dengan adanya peran penting dari kegiatan pengadaan barang/jasa pada Pemda untuk pengembangan perekonomian di daerah, maka kegiatan pengadaan barang/jasa

${ }^{1}$ Pada Pasal 1 angka (3) Undang-Undang Nomor 9 Tahun 2015 Tentang Pemerintahan Daerah (UU Nomor 9 Tahun 2015) ditentukan bahwa: "Pemerintah Daerah adalah Kepala Daerah sebagai unsur penyelenggara pemerintahan daerah yang memimpin pelaksanaan urusan pemerintahan yang menjadi kewenangan daerah otonom".

Pada angka (6), ditentukan bahwa: "Otonomi daerah adalah hak, wewenang, dan kewajiban daerah otonom untuk mengatur dan mengurus sendiri urusan pemerintahan dan kepentingan masyarakat setempat dalam sistem Negara Kesatuan Republik Indonesia”.

${ }_{2}$ Pemenuhan kebutuhan akan barang/jasa merupakan bagian penting yang tidak dapat dipisahkan dalam penyelenggaraan pemerintahan. Tersedianya barang/jasa, disamping merupakan bagian dari tugas dan tanggung jawab Pemerintah dalam upaya memenuhi kebutuhan rakyat, sekaligus kebutuhan Pemerintah dalam menjalankan pemerintahan. Lihat Purwosusilo, 2014, Aspek Hukum Pengadaan Barang dan Jasa, Kencana, Jakarta, hlm. 1.

${ }^{3}$ Pada Pasal 1 angka (1) Undang-Undang Nomor 25 Tahun 2009 Tentang Pelayanan Publik (UU Nomor 25 Tahun 2009), ditentukan bahwa: "Pelayanan publik adalah kegiatan atau rangkaian kegiatan dalam rangka pemenuhan kebutuhan pelayanan sesuai dengan peraturan perundang-undangan bagi setiap warga negara dan penduduk atas barang, jasa, dan/atau pelayanan administratif yang disediakan oleh penyelenggara pelayanan publik".

${ }^{4}$ Pada Pasal 1 angka (1) Perpres Nomor 16 Tahun 2018, ditentukan bahwa: "Pengadaan barang/jasa Pemerintah yang selanjutnya disebut pengadaan barang/jasa adalah kegiatan pengadaan barang/jasa oleh kementerian/lembaga/perangkat daerah yang dibiayai oleh APBN/APBD yang prosesnya sejak identifikasi kebutuhan, sampai dengan serah terima hasil pekerjaan".

Pada angka (29), ditentukan bahwa: "Barang adalah setiap benda baik berwujud maupun tidak berwujud, bergerak maupun tidak bergerak, yang dapat diperdagangkan, dipakai, dipergunakan atau dimanfaatkan oleh pengguna barang".

Berdasarkan Perpres Nomor 16 Tahun 2018, jasa dapat dibedakan menjadi 2 (dua) jenis. Pertama, jasa konsultasi. Kedua, jasa lainnya. Pada Pasal 1 angka (31) Perpres Nomor 16 Tahun 2018, ditentukan bahwa: "Jasa konsultansi adalah jasa layanan profesional yang membutuhkan keahlian tertentu di berbagai bidang keilmuan yang mengutamakan adanya olah pikir".

Pada angka (32), ditentukan bahwa: "Jasa lainnya adalah jasa non-konsultansi atau jasa yang membutuhkan peralatan, metodologi khusus, dan/atau keterampilan dalam suatu sistem tata kelola yang telah dikenal luas di dunia usaha untuk menyelesaikan suatu pekerjaan". 
pada Pemda, dalam implementasinya idealnya diprioritaskan memberdayakan UMKM. ${ }^{5}$ Hal ini ditegaskan berdasarkan ketentuan Pasal 13 ayat (1) huruf g UU Nomor 20 Tahun $2008 .{ }^{6}$

UMKM diselenggarakan dengan tujuan untuk menumbuhkan dan mengembangkan usaha dalam rangka membangun perekonomian nasional/daerah berdasarkan demokrasi ekonomi yang berkeadilan. Dengan prioritas diberdayakannya UMKM dalam kegiatan pengadaan barang/jasa pada Pemda, maka Pemda akan dapat menumbuhkan dan mengembangkan UMKM dalam rangka membangun perekonomian daerah berdasarkan demokrasi ekonomi yang berkeadilan.

Hal tersebut ditegaskan berdasarkan 2 (dua) hal. Pertama, UMKM dapat berjumlah besar dan hampir terdapat dalam setiap sektor ekonomi. Kedua, UMKM dapat menciptakan lebih banyak kesempatan dan penyerapan tenaga kerja. ${ }^{7}$ Dengan terbangunnya perekonomian daerah berdasarkan demokrasi ekonomi yang berkeadilan, Pemda dapat dikategorikan berhasil melaksanakan salah satu amanah yang menjadi tanggung jawabnya, sebagaimana yang telah ditentukan pada Pembukaan Undang-Undang Dasar Negara Negara Republik Indonesia Tahun 1945 (UUD 1945) Alinea ke IV, yakni memajukan kesejahteraan umum (di daerahnya).

Dengan adanya peran penting UMKM terkait kegiatan pengadaan barang/jasa pada Pemda untuk peningkatan pelayanan publik dan pengembangan perekonomian, adanya dasar hukum untuk memprioritaskan pemberdayaan UMKM dalam kegiatan pengadaan barang/jasa Pemda (Pasal 13 ayat $\{1\}$ huruf g UU Nomor 20 Tahun 2008), dan potensi UMKM dalam rangka membangun perekonomian nasional berdasarkan demokrasi ekonomi yang berkeadilan, perlu dikaji (secara normatif) mengenai kepastian hukum implementasi prioritas permberdayaan UMKM dalam pengadaan barang/jasa pada Pemda. Dengan demikian, pada masa yang akan datang tercipta kepastian hukum dan terimplementasi prioritas pemberdayaan UMKM dalam kegiatan pengadaan barang/jasa pada Pemda.

\section{B. PEMBAHASAN}

Masyarakat adil dan makmur berdasarkan Pancasila dan UUD 1945 harus diwujudkan melalui pembangunan perekonomian nasional berdasarkan demokrasi ekonomi. Sesuai

\footnotetext{
${ }^{5}$ Pada Pasal 1 angka (1) UU Nomor 20 Tahun 2008, ditentukan bahwa: "Usaha Mikro adalah usaha produktif milik orang-perorangan dan/atau badan usaha perorangan yang memenuhi kriteria Usaha Mikro sebagaimana diatur dalam undang-undang ini”.

Pada angka (2), ditentukan bahwa: "Usaha Kecil adalah usaha ekonomi produktif yang berdiri sendiri, yang dilakukan oleh orang-perorangan atau badan usaha yang bukan merupakan anak perusahaan atau bukan cabang perusahaan yang dimiliki, dikuasai, atau menjadi bagian baik langsung maupun tidak langsung dari Usaha Menengah atau Usaha Besar yang memenuhi kriteria Usaha Kecil sebagaimana dimaksud dalam undang-undang ini”.

Pada angka (3) ditentukan bahwa: "Usaha Menengah adalah usaha ekonomi produktif yang berdiri sendiri, yang dilakukan oleh orang-perseorangan atau badan usaha yang bukan merupakan anak perusahaan atau cabang perusahaan yang dimiliki, dikuasai, atau menjadi bagian baik langsung maupun tidak langsung dengan Usaha Kecil atau Usaha Besar dengan jumlah kekayaan bersih atau hasil penjualan tahunan sebagaimana diatur dalam undang-undang ini".

Pada angka (8), ditentukan pula bahwa: "Pemberdayaan adalah upaya yang dilakukan Pemerintah, Pemerintah Daerah, dunia usaha, dan masyarakat secara sinergis dalam bentuk penumbuhan iklim dan pengembangan usaha terhadap Usaha Mikro, Kecil, dan Menengah sehingga mampu tumbuh dan berkembang menjadi usaha yang tangguh dan mandiri".

${ }^{6}$ Pasal 13 ayat (1) huruf g UU Nomor 20 Tahun 2008, menentukan bahwa: “Aspek kesempatan berusaha sebagaimana dimaksud dalam Pasal 7 ayat (1) huruf f ditujukan untuk: g. Memprioritaskan pengadaan barang atau jasa dan pemborongan kerja Pemerintah dan Pemerintah Daerah".

${ }^{7}$ Pasal 1 angka (2) Undang-Undang Nomor 13 Tahun 2003 Tentang Ketenagakerjaan (UU Nomor 13 Tahun 2003), menentukan bahwa: "Tenaga kerja adalah setiap orang yang mampu melakukan pekerjaan guna menghasilkan barang dan/atau jasa baik untuk memenuhi kebutuhan sendiri maupun untuk masyarakat”.
} 
dengan amanat Ketetapan Majelis Permusyawaratan Rakyat Republik Indonesia Nomor XVI/MPR-RI/1998 Tentang Politik Ekonomi Dalam Rangka Demokrasi Ekonomi (Tap MPR Nomor XVI/MPR-RI/1998), UMKM perlu diberdayakan sebagai bagian integral ekonomi rakyat yang mempunyai kedudukan, peran, dan potensi strategis untuk mewujudkan struktur perekonomian nasional yang makin seimbang, berkembang, dan berkeadilan. Pemberdayaan UMKM perlu diselenggarakan secara menyeluruh, optimal, dan berkesinambungan melalui pengembangan iklim yang kondusif, pemberian kesempatan berusaha, dukungan, perlindungan, dan pengembangan usaha seluas-luasnya, sehingga mampu meningkatkan kedudukan, peran, dan potensi UMKM dalam mewujudkan pertumbuhan ekonomi, pemerataan dan peningkatan pendapatan rakyat, penciptaan lapangan kerja, dan pengentasan kemiskinan.

Ada 5 (lima) prinsip pemberdayaan UMKM. Pertama, penumbuhan kemandirian, kebersamaan, dan kewirausahaan UMKM untuk berkarya dengan prakarsa sendiri. Kedua, perwujudan kebijakan publik yang transparan, akuntabel, dan berkeadilan. Ketiga, pengembangan usaha berbasis potensi daerah dan berorientasi pasar sesuai dengan kompetensi UMKM. Keempat, peningkatan daya saing UMKM. Kelima, penyelenggaraan perencanaan, pelaksanaan, dan pengendalian secara terpadu.

Sesuai dengan ketentuan Pasal 5 UU Nomor 20 Tahun 2008, ada 3 (tiga) tujuan pemberdayaan UMKM. Pertama, mewujudkan struktur perekonomian nasional yang seimbang, berkembang, dan berkeadilan. Kedua, menumbuhkan dan mengembangkan kemampuan UMKM menjadi usaha yang tangguh dan mandiri. Ketiga, meningkatkan peran UMKM dalam pembangunan daerah, penciptaan lapangan kerja, pemerataan pendapatan, pertumbuhan ekonomi, dan pengentasan rakyat dari kemiskinan.

UMKM merupakan badan usaha. Umumnya badan usaha UMKM berbentuk Usaha Dagang (UD) ${ }^{8} /$ Perusahaan Dagang (PD) ${ }^{9} /$ Perusahaan Perseorangan, Commanditaire Vennootschap (CV). ${ }^{10}$ Bentuk usaha swasta ini (UD/PD, CV) adalah bentuk usaha yang

${ }^{8}$ UD adalah suatu badan usaha yang dijalankan secara mandiri oleh 1 (satu) orang saja dan tidak memerlukan partner dalam berusaha. Kalaupun ada yang membantu usaha tersebut, kedudukannya tidak sama dengan pemilik UD, tetapi hanya bertindak sebagai karyawan atau bawahan UD. Lihat Irma Devita Purnamasari, 2010, Kiat-kiat Cerdas, Mudah, dan Bijak Mendirikan Badan Usaha, Mizan Pustaka, Bandung, hlm. 5.

UD merupakan bentuk usaha yang paling sederhana dan sudah umum ditemui dalam praktek bisnis. UD dimiliki oleh 1 (satu) orang sebagai pengusahanya, dengan modal sendiri yang melakukan kegiatan usaha guna memperoleh keuntungan. Dalam aktivitas operasional perusahaan, UD sering melibatkan orang-orang, baik sebagai pekerja atau buruh atau pembantu dalam perusahaan, sedangkan pemilik atau pengusaha perusahaan tetap tunggal (hanya 1 s satu\} orang). Pemilik bertanggungjawab menanggung resiko dan menikmati keuntungan sendiri, sebaliknya orang-orang seperti pekerja atau tenaga kerja adalah merupakan orang yang bekerja dibawah pimpinan dengan menerima upah. Jika dilihat dari segi pengaturannya, tidak ada pengaturan secara resmi dalam bentuk perundang-undangan tentang UD. Namun demikian dalam praktek bisnis, UD ini eksistensinya diakui masyarakat. Mengingat belum diatur dalam undang-undang, maka baginya berlaku hukum kebiasaan dan jurisprudensi. Lihat juga I Dewa Ayu Dwi Mayasari, 2017, Tanggung Jawab Usaha Dagang Sebagai Perusahaan Perseorangan Terhadap Para Kreditur, Laporan Penelitian, Fakultas Hukum, Universitas Udayana, Bali, hlm. 12.

${ }^{9} \mathrm{PD}$ adalah perusahaan perseorangan yang dilakukan oleh seorang pengusaha. PD dapat dikelola oleh 1 (satu) orang atau lebih, modal milik sendiri. PD belum diatur secara khusus dalam undang-undang, tetapi dalam praktek diterima sebagai pelaku usaha. Lihat Sentosa Sembiring, 2001, Hukum Dagang, Citra Aditya Bakti, Bandung, hlm. 18.

${ }^{10} \mathrm{CV}$ merupakan perkumpulan yang tidak berbadan hukum. Menurut Robert W. Emerson, pada dasarnya, sebagian besar negara mengenal 3 (tiga) bentuk organisasi perusahaan. Pertama, perusahaan perseorangan (sole proprietorship or sole trader). Kedua, perusahaan persekutuan (parnertship). Ketiga, perusahaan perseroan (company or corporation). Lihat Robert W. Emerson, 2004, Business Law, Barron's Educational Series, New York, hlm. 296. Lihat juga Ida Bagus Abhimantara, 2019, Kedudukan Persekutuan Komanditer (Commanditaire 
modalnya dimiliki seluruh atau sebagian besar oleh pihak swasta baik secara individu (perseorangan) maupun kelompok. ${ }^{11}$

Telah ditegaskan bahwa pemenuhan kebutuhan Pemda akan barang/jasa yang dibutuhkan sebagai upaya memenuhi kebutuhan masyarakat dan memenuhi kebutuhan Pemda dalam menyelenggarakan pemerintahan daerah, dapat dilakukan melalui kegiatan pengadaan barang/jasa. Kegiatan pengadaan barang/jasa pada Pemda mempunyai peran penting dalam pelaksanaan pembangunan untuk peningkatan pelayanan publik dan khususnya untuk pengembangan perekonomian.

Kegiatan pengadaan barang/jasa pada Pemda sebagai upaya memenuhi kebutuhan masyarakat dan memenuhi kebutuhan Pemda dalam menyelenggarakan pemerintahan daerah haruslah dilakukan sesuai dengan ketentuan Perpres Nomor 16 Tahun 2018. Terkait dengan adanya peran penting dari kegiatan pengadaan barang/jasa Pemda untuk pengembangan perekonomian, berdasarkan ketentuan Pasal 13 ayat (1) huruf g UU Nomor 20 Tahun 2008, maka kegiatan pengadaan barang/jasa pada Pemda, dalam implementasinya idealnya memprioritaskan pemberdayaan UMKM. Untuk itu perlu dikaji mengenai kepastian hukum (secara normatif) implementasi prioritas pemberdayaan UMKM dalam pengadaan

Venootschap) Sebagai Coorporate Guarantee, Jurnal Notaire, Volume 2, Nomor 3, Magister Kenotariatan, Fakultas Hukum, Universitas Airlangga, Surabaya, hlm. 360.

Pada dasarnya CV bukan badan hukum, tetapi mempunyai kekayaan tersendiri dan dapat ditagih pihak ketiga, bila tidak cukup menjadi tanggung jawab sekutu pengurus secara pribadi untuk keseluruhan. Terdapat 3 (tiga) jenis CV. Pertama, CV diam-diam. Jenis ini belum menyatakan diri secara terbuka sebagai CV. Bagi orang luar jenis usaha ini masih dianggap usaha dagang biasa. Kedua, CV terang-terangan. Jenis ini telah menyatakan diri secara terbuka kepada pihak ketiga. Hal ini terlihat dengan dibuatnya akta pendirian CV oleh Notaris dan akta pendirian telah didaftarkan di daftar perusahaan. Ketiga, CV dengan saham. Munculnya CV jenis ini karena dalam perkembangan CV membutuhkan modal. Untuk mengatasi masalah kekurangan modal dapat dibagi atas beberapa saham masing-masing komandataris dapat memiliki 1 (satu) atas beberapa saham. Lihat Krisnadi Nasution, dan Alvin Kurniawan, 2019, Pendaftaran Commanditaire Venootschap (CV) Setelah Terbitnya Permenkumham Nomor 17 Tahun 2018, Jurnal LPPM, Volume 4, Nomor 1, Universitas 17 Agustus 1945, Surabaya, hlm. 56.

Keberadaan CV dalam lalu lintas bisnis telah dikenal masyarakat, terutama pengusaha, sebagai salah satu bentuk badan usaha. Dasar pengaturan CV dalam Kitab Undang-Undang Hukum Dagang (KUHD) tidak diatur secara khusus/tersendiri sebagaimana persekutuan firma dan persekutuan perdata (maatschap), namun beberapa kalangan Ahli hukum berpendapat bahwa bagi CV dapat diberlakukan terhadap pasal-pasal mengenai persekutuan firma maupun persekutuan perdata. Ketentuan CV terdapat pada Pasal 19, Pasal 20, Pasal 21, dan Pasal 32 KUHD. Lihat juga I.G. Rai Widjaya, 2005, Hukum Perusahaan, Kesaint Blanc, Jakarta, hlm. 1.

Ketentuan Pasal 19 sampai dengan Pasal 21 KUHD yang mengatur tentang Firma jika dikaji lebih jauh, jelaslah bahwa CV adalah Firma dengan bentuk khusus. Kekhususannya itu terletak pada eksistensi sekutu komanditer yang tidak ada pada Firma. Firma hanya mempunyai sekutu aktif yang disebut "firmant", sedangkan pada CV selain ada sekutu aktif juga ada sekutu komanditer atau sekutu pasif (sleeping partner). Lihat Soekardono, 1991, Hukum Dagang Indonesia, Rajawali Pers, Jakarta, hlm. 102.

Sebelumnya pendirian CV diatur dalam KUHD. Disebabkan karena aturan dalam KUHD dinilai kurang bisa menfasilitasi kebutuhan pada saat ini, maka kemudian Peraturan Pemerintah Nomor 24 Tahun 2018 Tentang Pelayanan Perizinan Berusaha Terintegrasi Secara Elektronik (PP Nomor 24 Tahun 2018), yang kemudian diperjelas lagi dengan Peraturan Menteri Hukum dan Hak Asasi Manusia Nomor 17 Tahun 2018 Tentang Pendaftaran Persekutuan Komanditer, Persekutuan Firma, dan Persekutuan Perdata (Permenkumham Nomor 17 Tahun 2018). Indonesia tidak merupakan negara yang paling mudah untuk mendirikan perusahaan baru atau untuk berperan aktif dibidang bisnis. Apabila sebelumnya pendaftaran dilakukan melalui pengadilan, tertanggal 1 Agustus 2018 sudah mulai berlaku Permenkumham Nomor 17 Tahun 2018, yang mensyaratkan pendaftaran harus dilakukan melalui Sistem Administrasi Badan Usaha (SABU) pada Direktorat Administrasi Hukum Umum (Direktorat AHU). Penerapan pendaftaran online ini mengadopsi sistem pendaftaran online Perseroan Terbatas (PT) yang sudah berlangsung hingga saat ini. Lihat juga Krisnadi Nasution, dan Alvin Kurniawan, Op.cit, hlm. 51.

11 Sanusi Bintang, dan Dahlan, 2000, Pokok-pokok Hukum Ekonomi dan Bisnis, Citra Aditya Bakti, Bandung, hlm. 4. 
barang/jasa pada Pemda. Dengan demikian pada masa yang akan datang tercipta kepastian hukum dan terimplementasi prioritas pemberdayaan UMKM dalam kegiatan pengadaan barang/jasa pada Pemda.

Berdasarkan Teori Kepastian Hukum yang dikemukakan Gustav Radbruch, kepastian hukum adalah kepastian tentang hukum itu sendiri. Ada 4 (empat) hal yang berhubungan dengan makna kepastian hukum. Pertama, bahwa hukum itu positif, artinya adalah perundang-undangan. Kedua, bahwa hukum itu didasarkan pada fakta, bukan suatu rumusan tentang penilaian yang nanti akan dilakukan oleh Hakim. Ketiga, bahwa fakta itu harus dirumuskan dengan cara yang jelas sehingga menghindari kekeliruan dalam pemaknaan, juga mudah dijalankan. Keempat, Hukum Positif itu tidak boleh sering diubah-ubah. ${ }^{12}$

Kepastian hukum merupakan salah satu tujuan hukum. Lebih lanjut menurut Gustav Radbruch, dalam pengertian hukum dapat dibedakan 3 (tiga) aspek, yang ketiganya diperlukan untuk sampai pada pengertian hukum yang memadai. Pertama, keadilan dalam arti yang sempit. Aspek keadilan ini berarti kesamaan hak untuk semua orang di depan pengadilan. Kedua, tujuan keadilan atau finalitas. Aspek ini menentukan isi hukum, sebab isi hukum memang sesuai dengan tujuan yang hendak dicapai. Ketiga, kepastian hukum atau legalitas. Aspek ini menjamin bahwa hukum dapat berfungsi sebagai peraturan yang harus ditaati. $^{13}$

Masalah kepastian hukum dalam kaitan dengan pelaksanaan hukum memang sama sekali tidak dapat dilepaskan sama sekali dari perilaku manusia. Kepastian hukum bukan mengikuti prinsip pencet tombol, melainkan sesuatu yang cukup rumit, yang banyak berkaitan dengan faktor diluar hukum itu sendiri. Menurut Gustav Radbruch, kepastian hukum adalah kepastian dari peraturan itu sendiri atau kepastian peraturan. ${ }^{14}$ Kepastian hukum merupakan pertanyaan yang hanya bisa dijawab secara normatif, bukan sosiologi. ${ }^{15}$

Kepastian hukum secara normatif adalah ketika suatu peraturan dibuat dan diundangkan secara pasti karena mengatur secara jelas dan logis. Jelas dalam artian tidak menimbulkan keragu-raguan dan logis. Jelas juga dalam artian menjadi suatu sistem norma dengan norma lain sehingga tidak berbenturan atau menimbulkan konflik norma. Kepastian hukum menunjuk kepada pemberlakuan hukum yang jelas, tetap, konsisten dan konsekuen yang pelaksanaannya tidak dapat dipengaruhi oleh keadaan-keadaan yang sifatnya subjektif. Kepastian dan keadilan bukanlah sekedar tuntutan moral, melainkan secara faktual mencirikan hukum. Suatu hukum yang tidak pasti dan tidak mau adil bukan sekedar hukum yang buruk. ${ }^{16}$

Kepastian hukum merupakan jaminan mengenai hukum yang berisi keadilan. Normanorma yang memajukan keadilan harus sungguh-sungguh berfungsi sebagai peraturan yang ditaati. Menurut Gustav Radbruch, keadilan dan kepastian hukum merupakan bagian-bagian

${ }^{12}$ Satjipto Rahardjo, 2006, Hukum Dalam Jagat Ketertiban, Universitas Kristen Indonesia Press, Jakarta, hlm. 135-136.

13 Theo Huijbers, 1982, Filsafat Hukum Dalam Lintasan Sejarah, Kanisius, Yogyakarta, hlm. 163.

Aspek keadilan menunjuk pada kesamaan hak didepan hukum. Aspek finalitas menunjuk kepada tujuan keadilan, yaitu memajukan kebaikan dalam hidup manusia. Aspek ini menentukan isi hukum. Aspek kepastian menunjuk pada jaminan bahwa hukum (yang berisi keadilan dan norma-norma yang memajukan kebaikan), benar-benar berfungsi sebagai peraturan yang ditaati. Ditegaskan bahwa, 2 (dua) aspek pertama merupakan kerangka ideal dari hukum, sedangkan aspek ketiga (kepastian) merupakan kerangka operasional hukum. Lihat Bernard L. Tanya, et.al., 2013, Teori Hukum (Strategi Tertib Manusia Lintas Ruang dan Generasi), Genta Publishing, Yogyakarta, hlm. 118.

14 M. Yahya Harahap, 2002, Pembahasan Permasalahan dan Penerapan KUHP (Penyidikan dan Penuntutan), Sinar Grafika, Jakarta, hlm. 76.

15 Dominikus Rato, 2010, Filsafat Hukum Mencari (Memahami dan Memahami Hukum), Laksbang Pressindo, Yogyakarta, hlm. 59.

${ }^{16}$ Lihat juga C.S.T. Kansil, 2009, Kamus Istilah Aneka Hukum, Jala Permata, Jakarta, hlm. 385. 
yang tetap dari hukum. Lebih lanjut, menurut Gustav Radbruch, keadilan dan kepastian hukum harus diperhatikan, kepastian hukum harus dijaga demi keamanan dan ketertiban suatu negara, akhirnya Hukum Positif harus selalu ditaati. Berdasarkan Teori Kepastian Hukum nilai yang ingin dicapai yaitu nilai keadilan dan kebahagiaan. ${ }^{17}$

Berdasarkan berbagai pemaparan yang telah ada mengenai kepastian hukum, ditegaskan bahwa kepastian hukum (secara normatif) adalah ketika suatu peraturan dibuat dan diundangkan secara pasti karena mengatur secara jelas dan logis. Jelas dalam artian tidak menimbulkan keragu-raguan (multi tafsir) dan logis. Jelas juga dalam artian menjadi suatu sistem norma dengan norma lain sehingga tidak berbenturan atau menimbulkan konflik norma.

Kepastian hukum menunjuk kepada pemberlakuan hukum yang jelas, tetap, konsisten dan konsekuen yang pelaksanaannya tidak dapat dipengaruhi oleh keadaan-keadaan yang sifatnya subjektif. Mengenai kepastian hukum implementasi prioritas pemberdayaan UMKM dalam pengadaan barang/jasa Pemda, secara aturan khusus, dikaji berdasarkan ketentuan dalam Perpres Nomor 16 Tahun 2018. Selain itu juga dikaji berdasarkan ketentuan dalam UU Nomor 20 Tahun 2008 (ketentuan lainnya, selain ketentuan Pasal 13 ayat (1) huruf g).

Pada bagian Menimbang huruf a dan b Perpres Nomor 16 Tahun 2018, ditentukan:

a. "Bahwa pengadaan barang/jasa Pemerintah mempunyai peran penting dalam pelaksanaan pembangunan nasional untuk peningkatan pelayanan publik dan pengembangan perekonomian nasional dan daerah;

b. Bahwa untuk mewujudkan pengadaan barang/jasa Pemerintah sebagaimana dimaksud pada huruf a, perlu pengaturan pengadaan barang/jasa yang memberikan pemenuhan nilai manfaat yang sebesar-besarnya (value for money) dan kontribusi dalam peningkatan penggunaan produk dalam negeri, peningkatan peran Usaha Mikro, Usaha Kecil, dan Usaha Menengah serta pembangunan berkelanjutan”.

Berdasarkan bagian Menimbang Perpres Nomor 16 Tahun 2018 tersebut, khususnya huruf $\mathrm{b}$, ditegaskan bahwa kegiatan pengadaan barang/jasa pada Pemda haruslah meningkatkan peran (pemberdayaan) UMKM guna terlaksananya peningkatan pelayanan publik dan pengembangan perekonomian daerah.

Pada Pasal 4 Perpres Nomor 16 Tahun 2018, ditentukan bahwa: "Pengadaan barang/jasa bertujuan untuk:

a. Menghasilkan barang/jasa yang tepat dari setiap uang yang dibelanjakan, diukur dari aspek kualitas, jumlah, waktu, biaya, lokasi, dan penyedia;

b. Meningkatkan penggunaan produk dalam negeri;

c. Meningkatkan peran serta Usaha Mikro, Usaha Kecil, dan Usaha Menengah;

d. Meningkatkan peran pelaku usaha nasional;

e. Mendukung pelaksanaan penelitian dan pemanfaatan barang/jasa hasil penelitian;

f. Meningkatkan keikutsertaan industri kreatif;

g. Mendorong pemerataan ekonorni; dan

h. Mendorong pengadaan berkelanjutan".

\footnotetext{
${ }^{17}$ Achmad Ali, 2002, Menguak Tabir Hukum (Suatu Kajian Filosofis dan Sosiologis), Gunung Agung, Jakarta, hlm. 95.

Menurut E. Utrecht, kepastian hukum mengandung 2 (dua) pengertian. Pertama, adanya aturan yang bersifat umum membuat individu mengetahui perbuatan yang boleh ataupun yang tidak boleh dilakukan. Kedua, berupa keamanan hukum bagi individu dari kesewenangan Pemerintah, karena dengan adanya aturan yang bersifat umum, individu dapat mengetahui mengenai semua yang boleh dibebankan atau dilakukan oleh negara terhadap individu. Lihat Riduan Syahrani, 1999, Rangkuman Intisari Ilmu Hukum, Citra Aditya Bakti, Bandung, hlm. 23.
} 
Berdasarkan ketentuan Pasal 4 Perpres Nomor 16 Tahun 2018 di atas, khususnya huruf c, ditegaskan bahwa peran serta (pemberdayaan) UMKM harus ditingkatkan oleh Pemda dalam kegiatan pengadaan barang/jasa.

Pada Pasal 5 Perpres Nomor 16 Tahun 2018, ditentukan bahwa: "Kebijakan pengadaan barang/jasa meliputi:

a. Meningkatkan kualitas perencanaan pengadaan barang/jasa;

b. Melaksanakan pengadaan barang/jasa yang lebih transparan, terbuka, dan kompetitif;

c. Memperkuat kapasitas kelembagaan dan Sumber Daya Manusia pengadaan barang/jasa;

d. Mengembangkan E-market place pengadaan barang/jasa;

e. Menggunakan teknologi informasi dan komunikasi, serta transaksi elektronik;

f. Mendorong penggunaan barang/jasa dalam negeri dan Standar Nasional Indonesia (SNI);

g. Memberikan kesempatan kepada Usaha Mikro, Usaha Kecil, dan Usaha Menengah;

h. Mendorong pelaksanaan penelitian dan industri kreatif; dan

i. Melaksanakan pengadaan berkelanjutan".

Berdasarkan ketentuan Pasal 5 Perpres Nomor 16 Tahun 2018 tersebut, khususnya huruf g, ditegaskan bahwa kebijakan untuk kegiatan pengadaan barang/jasa pada Pemda harus memberikan kesempatan (memberdayakan) UMKM.

Pada Pasal 65 Perpres Nomor 16 Tahun 2018, ditentukan bahwa:

1. "Usaha kecil terdiri atas Usaha Mikro dan Usaha Kecil;

2. Dalam pengadaan barang/jasa, PA/KPA memperluas peran serta usaha kecil;

3. Pemaketan dilakukan dengan menetapkan sebanyak-banyaknya paket untuk Usaha Kecil tanpa mengabaikan prinsip efisiensi, persaingan usaha yang sehat, kesatuan sistem, dan kualitas kemampuan teknis;

4. Nilai paket pengadaan barang/pekerjaan konstruksi/jasa lainnya paling banyak Rp. 2.500.000.000,00- (Dua Miliar Lima Ratus Juta Rupiah), dicadangkan dan peruntukannya bagi Usaha Kecil, kecuali untuk paket pekerjaan yang menuntut kemampuan teknis yang tidak dapat dipenuhi oleh Usaha Kecil;

5. LKPP dan kementerian/lembaga/Pemerintah Daerah memperluas peran serta Usaha Kecil dengan mencantumkan barang/jasa produksi Usaha Kecil dalam katalog elektronik;

6. Penyedia usaha non-kecil yang melaksanakan pekerjaan dapat melakukan kerja sama usaha dengan Usaha Kecil dalam bentuk kemitraan, sub kontrak, atau bentuk kerja sama lainnya, jika ada Usaha Kecil yang memiliki kemampuan dibidang yang bersangkutan". ${ }^{18}$

Berdasarkan ketentuan Pasal 65 Perpres Nomor 16 Tahun 2018 di atas, khususnya ayat (5), ditegaskan bahwa Pemerintah (LKPP dan kementerian/lembaga)/Pemda idealnya memperluas peran serta (pemberdayaan) UMKM (khususnya Usaha Mikro dan Usaha Kecil) dengan mencantumkan barang/jasa produksi Usaha Mikro dan Usaha Kecil dalam katalog elektronik.

18 Pada Pasal 1 angka (6) Perpres Nomor 16 Tahun 2018, ditentukan bahwa: "Lembaga Kebijakan Pengadaan Barang/Jasa Pemerintah yang selanjutnya disingkat LKPP adalah lembaga Pemerintah yang bertugas mengembangkan dan merumuskan kebijakan pengadaan barang/jasa Pemerintah".

Pada angka (7), ditentukan bahwa: "Pengguna Anggaran yang selanjutnya disingkat PA adalah pejabat pemegang kewenangan penggunaan anggaran kementerian negara/lembaga/perangkat daerah".

Pada angka (8), ditentukan bahwa: "Kuasa Pengguna Anggaran pada pelaksanaan APBN yang selanjutnya disingkat KPA adalah pejabat yang memperoleh kuasa dari PA untuk melaksanakan sebagian kewenangan dan tanggung jawab penggunaan anggaran pada kementerian negara/lembaga yang bersangkutan”.

Pada angka (9), ditentukan pula bahwa: "Kuasa Pengguna Anggaran pada pelaksanaan APBD yang selanjutnya disingkat KPA adalah pejabat yang diberi kuasa untuk melaksanakan sebagian kewenangan pengguna anggaran dalam melaksanakan sebagian tugas dan fungsi perangkat daerah”. 
Berdasarkan ketentuan Pasal 4 huruf c, Pasal 5 huruf g, dan Pasal 65 ayat (5) Perpres Nomor 16 Tahun 2018, ditegaskan 3 (tiga) hal mengenai kedudukan UMKM dalam Hukum Pengadaan Barang/Jasa Pemerintah. Pertama, UMKM mempunyai peran yang harus ditingkatkan pemberdayaannya dalam kegiatan pengadaan barang/jasa pada Pemerintah/Pemda. Kedua, kebijakan kegiatan pengadaan barang/jasa Pemerintah/Pemda harus memberikan kesempatan pemberdayaan UMKM. Ketiga, Pemerintah/Pemda harus memperluas pemberdayaan UMKM.

Berdasarkan 3 (tiga) hal yang ditegaskan tersebut, dikaitkan dengan Teori Kepastian Hukum, ditegaskan pula bahwa dalam Hukum Pengadaan Barang/Jasa Pemerintah, sesuai dengan Perpres Nomor 16 Tahun 2018, UMKM memiliki kedudukan penting yang implementasi pemberdayaannya harus ditingkatkan melalui kebijakan, diberikan kesempatan, dan diperluas pula pemberdayaannya dalam kegiatan pengadaan barang/jasa pada Pemerintah/Pemda. Hal tersebut dilakukan guna terlaksananya pembangunan untuk peningkatan pelayanan publik dan pengembangan perekonomian berdasarkan demokrasi ekonomi yang berkeadilan guna terealisasinya kesejahteraan umum nasional/daerah.

Meskipun telah ada ketentuan Pasal 13 ayat (1) huruf g UU Nomor 20 Tahun 2008 (prioritas pemberdayaan UMKM dalam pengadaan barang/jasa Pemerintah/Pemda), dan Pasal 4 huruf c, Pasal 5 huruf g, serta Pasal 65 ayat (5) Perpres Nomor 16 Tahun 2018 (pemberdayaan UMKM dalam pengadaan barang/jasa Pemerintah/Pemda), akan tetapi dikaji lebih lanjut berdasarkan ketentuan dalam UU Nomor 20 Tahun 2008 dan Perpres Nomor 16 Tahun 2018, dalam ke 2 (dua) peraturan tersebut belum ada ketentuan pasal yang menentukan mengenai kewajiban hukum Pemerintah/Pemda untuk dalam implementasinya (dalam pelaksanaan kegiatan pengadaan barang/jasa) prioritas memberdayakan UMKM. Hal ini tentunya belum sepenuhnya menciptakan kepastian hukum perihal prioritas pemberdayaan UMKM dalam pengadaan barang/jasa pada Pemerintah/Pemda. Selain itu membuktikan bahwa Dewan Perwakilan Rakyat (DPR) dan/atau Pemerintah belum memiliki political will yang sungguh-sungguh mengimplementasikan prioritas pemberdayaan UMKM dalam pengadaan barang/jasa pada Pemerintah/Pemda.

Dengan demikian, agar dapat tercipta kepastian hukum perihal implementasi prioritas pemberdayaan UMKM dalam kegiatan pengadaan barang/jasa pada Pemda di masa yang akan datang, diharapkan DPR dan Pemerintah dapat segera merevisi UU Nomor 20 Tahun 2008, dengan menambahkan ketentuan pasal yang menentukan mengenai kewajiban hukum Pemerintah/Pemda mengimplementasikan prioritas pemberdayaan UMKM dalam kegiatan pengadaan barang/jasa pada Pemerintah/Pemda. Selain itu juga diharapkan agar Pemerintah dapat segera merevisi Perpres Nomor 16 Tahun 2018, dengan menambahkan ketentuan pasal yang menentukan mengenai kewajiban hukum Pemerintah/Pemda mengimplementasikan prioritas pemberdayaan UMKM dalam kegiatan pengadaan barang/jasa pada Pemerintah/Pemda.

Revisi UU Nomor 20 Tahun 2008 tersebut juga harus ditindaklanjuti pula oleh Pemda dengan menerbitkan Peraturan Daerah (Perda) mengenai kewajiban hukum pegawai Pemda mengimplementasikan prioritas pemberdayaan UMKM dalam kegiatan pengadaan barang/jasa. Dengan demikian dapat lebih tercipta kepastian hukum mengenai implementasi prioritas pemberdayaan UMKM dalam kegiatan pengadaan barang/jasa Pemda, guna terlaksananya pembangunan untuk peningkatan pelayanan publik dan pengembangan perekonomian di daerah (yang berdasarkan demokrasi ekonomi yang berkeadilan), sehingga terealisasi kesejahteraan umum yang tentunya menciptakan kebahagiaan, yang merupakan nilai yang ingin dicapai berdasarkan Teori Kepastian Hukum. 


\section{KESIMPULAN}

Dengan adanya peran penting kegiatan pengadaan barang/jasa pada Pemda untuk pengembangan perekonomian di daerah, maka kegiatan pengadaan barang/jasa pada Pemda, idealnya dalam implementasinya haruslah diprioritaskan memberdayakan UMKM. Kepastian hukum mengenai implementasi prioritas permberdayaan UMKM dalam pengadaan barang/jasa pada Pemda, belum sepenuhnya tercipta. Hal ini ditegaskan karena belum ada ketentuan pasal dalam UU Nomor 20 Tahun 2008 maupun dalam Perpres Nomor 16 Tahun 2018, yang menentukan mengenai kewajiban hukum Pemda untuk mengimplementasikan prioritas pemberdayaan UMKM dalam kegiatan pengadaan barang/jasa pada Pemda.

Agar dapat tercipta kepastian hukum pada masa yang akan datang, diharapkan DPR dan Pemerintah dapat segera merevisi UU Nomor 20 Tahun 2008, dengan menambahkan ketentuan pasal yang menentukan mengenai kewajiban hukum Pemda mengimplementasikan prioritas pemberdayaan UMKM dalam kegiatan pengadaan barang/jasa pada Pemda. Selain itu juga diharapkan agar Pemerintah dapat segera merevisi Perpres Nomor 16 Tahun 2018, dengan menambahkan ketentuan pasal yang menentukan mengenai kewajiban hukum Pemda mengimplementasikan prioritas pemberdayaan UMKM dalam kegiatan pengadaan barang/jasa pada Pemda. Revisi UU Nomor 20 Tahun 2008 tersebut juga harus ditindaklanjuti pula oleh Pemda dengan menerbitkan Perda mengenai kewajiban hukum pegawai Pemda mengimplementasikan prioritas pemberdayaan UMKM dalam kegiatan pengadaan barang/jasa.

\section{DAFTAR PUSTAKA}

Ali, Achmad, 2002, Menguak Tabir Hukum (Suatu Kajian Filosofis dan Sosiologis), Gunung Agung, Jakarta.

Bintang, Sanusi, dan Dahlan, 2000, Pokok-pokok Hukum Ekonomi dan Bisnis, Citra Aditya Bakti, Bandung.

Emerson, Robert W., 2004, Business Law, Barron's Educational Series, New York.

Harahap, M. Yahya, 2002, Pembahasan Permasalahan dan Penerapan KUHP (Penyidikan dan Penuntutan), Sinar Grafika, Jakarta.

Huijbers, Theo, 1982, Filsafat Hukum Dalam Lintasan Sejarah, Kanisius, Yogyakarta.

Purnamasari, Irma Devita, 2010, Kiat-kiat Cerdas, Mudah, dan Bijak Mendirikan Badan Usaha, Mizan Pustaka, Bandung.

Purwosusilo, 2014, Aspek Hukum Pengadaan Barang dan Jasa, Kencana, Jakarta.

Rato, Dominikus, 2010, Filsafat Hukum Mencari (Memahami dan Memahami Hukum), Laksbang Pressindo, Yogyakarta.

Rahardjo, Satjipto, 2006, Hukum Dalam Jagat Ketertiban, Universitas Kristen Indonesia Press, Jakarta.

Soekardono, 1991, Hukum Dagang Indonesia, Rajawali Pers, Jakarta.

Sembiring, Sentosa, 2001, Hukum Dagang, Citra Aditya Bakti, Bandung.

Syahrani, Riduan, 1999, Rangkuman Intisari Ilmu Hukum, Citra Aditya Bakti, Bandung.

Tanya, Bernard L., et.al., 2013, Teori Hukum (Strategi Tertib Manusia Lintas Ruang dan Generasi), Genta Publishing, Yogyakarta.

Widjaya, I.G. Rai, 2005, Hukum Perusahaan, Kesaint Blanc, Jakarta.

Undang-Undang Dasar Negara Negara Republik Indonesia Tahun 1945.

Ketetapan Majelis Permusyawaratan Rakyat Republik Indonesia Nomor XVI/MPR-RI/1998

Tentang Politik Ekonomi Dalam Rangka Demokrasi Ekonomi.

Kitab Undang-Undang Hukum Dagang.

Undang-Undang Nomor 13 Tahun 2003 Tentang Ketenagakerjaan. 
Undang-Undang Nomor 20 Tahun 2008 Tentang Usaha Mikro, Kecil, dan Menengah.

Undang-Undang Nomor 25 Tahun 2009 Tentang Pelayanan Publik.

Undang-Undang Nomor 9 Tahun 2015 Tentang Pemerintahan Daerah.

Peraturan Pemerintah Nomor 24 Tahun 2018 Tentang Pelayanan Perizinan Berusaha Terintegrasi Secara Elektronik.

Peraturan Presiden Nomor 16 Tahun 2018 Tentang Pengadaan Barang/Jasa Pemerintah.

Peraturan Menteri Hukum dan Hak Asasi Manusia Nomor 17 Tahun 2018 Tentang Pendaftaran Persekutuan Komanditer, Persekutuan Firma, dan Persekutuan Perdata.

Mayasari, I Dewa Ayu Dwi, 2017, Tanggung Jawab Usaha Dagang Sebagai Perusahaan Perseorangan Terhadap Para Kreditur, Laporan Penelitian, Fakultas Hukum, Universitas Udayana, Bali.

Abhimantara, Ida Bagus, 2019, Kedudukan Persekutuan Komanditer (Commanditaire Venootschap) Sebagai Coorporate Guarantee, Jurnal Notaire, Volume 2, Nomor 3, Magister Kenotariatan, Fakultas Hukum, Universitas Airlangga, Surabaya.

Nasution, Krisnadi, dan Alvin Kurniawan, 2019, Pendaftaran Commanditaire Venootschap (CV) Setelah Terbitnya Permenkumham Nomor 17 Tahun 2018, Jurnal LPPM, Volume 4, Nomor 1, Universitas 17 Agustus 1945, Surabaya.

Kansil, C.S.T., 2009, Kamus Istilah Aneka Hukum, Jala Permata, Jakarta. 